\title{
Fractional composition of grain sorghum proteins depending on the variety
}

\author{
Irina Sazonova ${ }^{1,2, *}$, Vera Bychkova $^{1}$, and Anna Erokhina $^{1}$ \\ ${ }^{1}$ Federal State Funded Research Institution RosNIISK Rossorgo, 410050, Saratov, 1st Institute \\ passage, 4, Russian Federation \\ ${ }^{2}$ Federal State-Owned Publicly-Funded Institution of Higher Education Saratov GAU, 410012, \\ Saratov, Theater Square 1, Russian Federation
}

\begin{abstract}
Federal State Budgetary Scientific Institution RosNIISK Rossorgo were studied. The amount of protein in grain and its fractions was experimentally determined: albumin, globulins, glutelins and prolamins, a comparative analysis was carried out within each fraction and a conclusion was made about the highest biological value among the studied varieties. The results showed that sorghum seeds contain all four protein fractions, the highest content of which is albumin and glutel. The highest nutritional value was noted in the variety of sorghum Zhemchug, which contained the highest amount of albumin, characterized by a complete amino acid composition, and the lowest content of prolamins, which have a low balance of amino acids. In the varieties Kamelik and Locus, there was an insufficient content of complete proteins that make up the water-soluble and salt-soluble fractions in the grain of these plants. Grain sorghum varieties with the highest amount of protein (Pomegranate, Locus, Pearl and Bachelor) were characterized by a low level of alcohol-soluble protein fraction.
\end{abstract}

\section{Introduction}

Currently, production of specialized food products is rapidly developing, including those free from certain types of proteins, the presence of which is not recommended for medical reasons. The achievements of domestic and world science indicate that the market for functional products in the global aspect is growing [1, 2, 3, 4, 5, 6, 7]. Increasingly, in the food industry, crops are used that have high productivity, adapted to local conditions, which at the same time solve the problem of dietary protein - the main source of food for humans.

Grain sorghum is on a par with traditional food crops in protein content and is free of gluten, which causes celiac disease. Sorghum does not have an inedible shell like some other grains. This means it provides the body with even more fiber in addition to many other important nutrients and has a lower glycemic index, which is especially beneficial for people with blood sugar problems such as diabetes. Proteins of agricultural crops, including sorghum, are unequal in amino acid composition, solubility and digestibility. Therefore, the

* Corresponding author: iasazonova@mail.ru 
quality of crop production is assessed not only by the content, but also by the usefulness of proteins based on the study of their fractional composition.

Beginning with the classical works of T.B. Osborne, who proposed the classification of proteins by solubility, a number of studies were carried out to study the quantitative ratios and properties of protein substances in grain of various agricultural crops. Nevertheless, significant issues of great interest for grain processing technology remain unclear. This is due to the extreme complexity of the structure of protein substances, as a result of which there are many gaps even in such a simple issue as the quantitative ratio of various protein fractions.

Previously, scientists have studied the properties of proteins of various agricultural crops and their fractional composition $[8,9,10,11]$.

It has been proven that moisture-heat treatment in various temperature ranges affects the protein fractions of grain. Thus, it was found that wheat grain glutelins are most susceptible to high temperatures (above $60^{\circ} \mathrm{C}$ ) and had a greater ability to aggregate [12].

L.M. Bokova et al. studied the distribution of protein fractions in cereals and flour by planar gel permeation chromatography. The experimental results showed that the amount of protein fractions depends not only on its molecular weight, but also on the $\mathrm{pH}$ value of the medium [13].

Researches of N.V. Zaslavskaya are devoted to the study of the fractional composition of proteins in the grain of wheat-wheatgrass hybrids during the ripening of the culture and characterize the dependence of the intensity of biosynthesis of protein fractions on the stage of grain formation [14].

Of course, the study of the quality of the protein complex of grain in the varietal section of crops, including sorghum, will make it possible to identify genotypes with the most valuable nutritional properties for the processing industry and to conduct selection in this direction. Wherein, research of this kind, in particular of sorghum crops, is currently insufficient. Therefore, the study of the genotypic diversity of sorghum crops by the fractional composition of the protein is relevant.

The purpose of this study was to identify varieties of grain sorghum of the selection of the Federal State Budgetary Scientific Institution RosNIISK Rossorgo, which have the highest nutritional value in terms of the protein complex of grain.

\section{Methods}

As a research material, 14 samples of grain sorghum (Zhemchug, Granat, Volzhskoye 4, RSK-Oniks, RSK-Kakholong, RSK-Infiniti, RSK-Korall, Azart, Topaz, Avans, RSKKaskad, RSK-Lokus, Kamelik, Bakalavr) from own selection of the crop of 2020 were selected. All samples were preliminarily subjected to fine grinding and grinding in a mortar. The resulting flour was used for further study.

The amount of protein was investigated on a Spectral Star XT infrared analyzer by spectroscopy. Protein fractions were separated by extraction according to the Osborne scheme [15], which provides for the sequential extraction of proteins with distilled water, $0.5 \mathrm{M}$ potassium chloride solution, $70 \%$ ethanol solution, and $0.2 \%$ sodium hydroxide solution. Using the calculation, the albumin, globulin, glutelin, prolamine fractions and the insoluble residue were further determined.

Statistical processing of the results was carried out by univariate analysis of variance and statistical analysis of the sample in the AGROS of 2.09 versions [16]. 


\section{Results}

Previously, we studied the protein content in the grain of the above-described sorghum varieties (Figure 1).

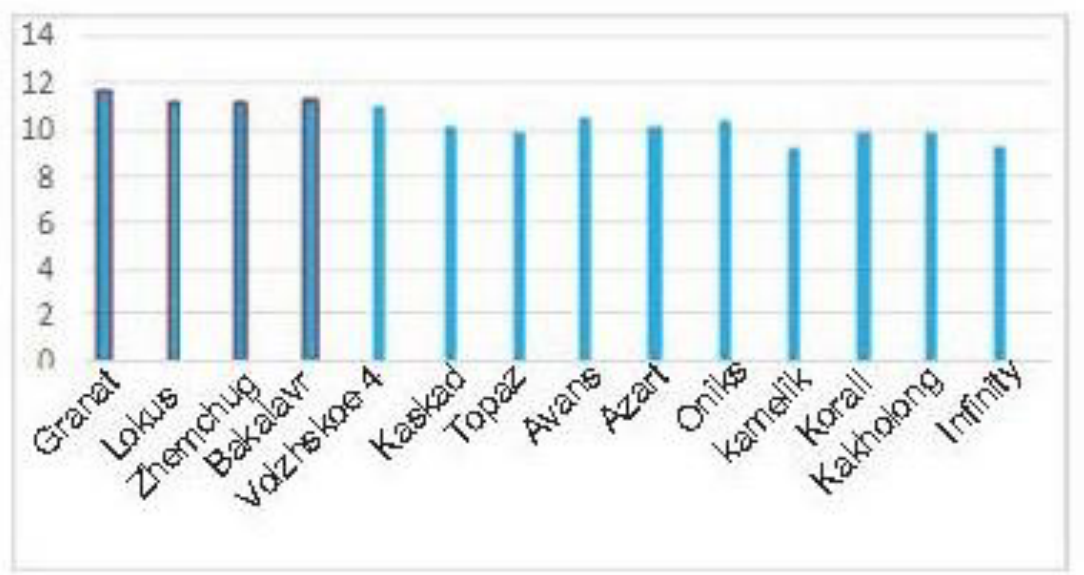

Fig. 1. Protein content in grain sorghum.

Varieties that differed in the greatest amount of protein - Granat, Lokus, Zhemchug, Bakalavr (from 11.67 to $11.01 \%$ ) were identified. In the rest of the samples selected for the study, the indicator for the amount of protein varied from 9.22 to $10.45 \%$, where the lowest value was observed in Kamelik variety.

By the method of sequential extraction, we found that all four protein fractions are present in sorghum seeds (Table 1). Wherein, taking into account the average value for varieties, the highest content is distinguished by the albumin and glutelin fractions: 2.37 and 2.36, respectively. The globulins in the grain of sorghum contained an average of 1.69 and the prolamin fraction was at the level of 1.78 .

Table 1. Fractional composition of protein in grain of sorghum varieties, $g / 100 \mathrm{~g}$ of dry matter.

\begin{tabular}{|l|c|c|c|c|c|}
\hline \multirow{2}{*}{ Variety } & \multicolumn{5}{|c|}{ Protein fractions } \\
\cline { 2 - 6 } & albumins & globulins & glutelins & prolamins & $\begin{array}{c}\text { insoluble } \\
\text { residue }\end{array}$ \\
\hline Onyx & $2.54 \mathrm{fg}$ & $1.98 \mathrm{fg}$ & $2.86 \mathrm{k}$ & $3.22 \mathrm{j}$ & $1.68 \mathrm{bc}$ \\
\hline Kakholong & $2.56 \mathrm{fg}$ & $1.65 \mathrm{bcd}$ & $2.80 \mathrm{jk}$ & $1.47 \mathrm{c}$ & $1.18 \mathrm{ab}$ \\
\hline Korall & $2.43 \mathrm{~d}-\mathrm{g}$ & $1.51 \mathrm{bc}$ & $1.42 \mathrm{a}$ & $2.70 \mathrm{i}$ & $1.87 \mathrm{bc}$ \\
\hline Zhemchug & $3.26 \mathrm{i}$ & $1.96 \mathrm{efg}$ & $2.22 \mathrm{ef}$ & $1.17 \mathrm{a}$ & $3.47 \mathrm{ghi}$ \\
\hline Volzhskoe 4 & $2.63 \mathrm{fg}$ & $1.61 \mathrm{bc}$ & $2.60 \mathrm{hi}$ & $2.18 \mathrm{fgh}$ & $0.89 \mathrm{a}$ \\
\hline Granat & $2.96 \mathrm{~h}$ & $2.09 \mathrm{~g}$ & $1.61 \mathrm{~b}$ & $1.17 \mathrm{a}$ & $3.09 \mathrm{~d}-\mathrm{g}$ \\
\hline Topaz & $2.37 \mathrm{def}$ & $1.69 \mathrm{~cd}$ & $2.65 \mathrm{ij}$ & $2.21 \mathrm{gh}$ & $2.17 \mathrm{c}$ \\
\hline Azart & $2.53 \mathrm{efg}$ & $1.68 \mathrm{~cd}$ & $2.60 \mathrm{ghi}$ & $1.41 \mathrm{bc}$ & $5.32 \mathrm{k}$ \\
\hline Kamelik & $1.06 \mathrm{a}$ & $0.71 \mathrm{a}$ & $4.64 \mathrm{l}$ & $1.31 \mathrm{ab}$ & $1.27 \mathrm{ab}$ \\
\hline Avans & $2.22 \mathrm{~cd}$ & $1.86 \mathrm{def}$ & $2.11 \mathrm{def}$ & $1.24 \mathrm{a}$ & $3.11 \mathrm{efg}$ \\
\hline Lokus & $1.75 \mathrm{~b}$ & $1.64 \mathrm{bcd}$ & $2.29 \mathrm{f}$ & $1.74 \mathrm{de}$ & $4.03 \mathrm{ij}$ \\
\hline Kaskad & $2.14 \mathrm{~cd}$ & $1.50 \mathrm{bc}$ & $2.09 \mathrm{de}$ & $2.30 \mathrm{~h}$ & $3.24 \mathrm{fg}$ \\
\hline Bakalavr & $2.07 \mathrm{c}$ & $1.42 \mathrm{~b}$ & $1.60 \mathrm{ab}$ & $1.19 \mathrm{a}$ & $4.03 \mathrm{hij}$ \\
\hline Infinity & $2.68 \mathrm{~g}$ & $2.36 \mathrm{~h}$ & $1.96 \mathrm{~cd}$ & $1.74 \mathrm{e}$ & $4.38 \mathrm{j}$ \\
\hline NSR & 0.261 & 0.221 & 0.172 & 0.145 & 0.702 \\
\hline
\end{tabular}




\begin{tabular}{|l|c|c|c|c|c|}
\hline F05 & $38,766^{*}$ & $27,918^{*}$ & $198,514^{*}$ & $182,567^{*}$ & $34,649^{*}$ \\
\hline Avg \pm errors & $2.37 \pm 0.10$ & $1.69 \pm 0.07$ & $2.36 \pm 0.15$ & $1.78 \pm 0.12$ & $2.85 \pm 0.26$ \\
\hline $\begin{array}{l}\text { Min-max } \\
\text { interval }\end{array}$ & $1.03-3.39$ & $0.68-2.54$ & $1.41-4.67$ & $1.05-3.24$ & $0.89-5.17$ \\
\hline V, \% & 22.30 & 22.75 & 33.30 & 35.83 & 47.39 \\
\hline
\end{tabular}

Note: $* \mathrm{p}<0.05$; the data for each variety, denoted with different letters, are significantly different at $\mathrm{p}<0.05$ according to Duncan's Multiple Comparisons Test.

The greatest amount of the most valuable in terms of the composition of amino acids, albumin, was found in Zhemchug variety. There was $10 \%$ less albumin in the protein of the grain of the Granat variety. In a number of varieties (Oniks, Kakholong, Korall, Volzhskoye 4, Azart, Infiniti), the albumin fraction was $27 \%$ lower than in Zhemchug and was at the same level, with an average value of 2.56. The lowest content of albumin in protein was in the grain of the Kamelik variety, which differed by two times with the highest indicator. A similar trend for this variety was observed in the amount of globulins in the protein - this fraction was at the lowest level in comparison with other varieties. The highest value of salt-soluble proteins was noted in the Infinity cultivar (2.36). Slightly less (by $17 \%$ ) globulins in the protein were in Oniks, Zhemchug i Granat varieties, on average 2.01. The bulk of sorghum, namely, Kakholong, Korall, Volzhskoye 4, Topaz, Azart, Lokus, kaskad, Bakalavr varieties contained an average of 1.59 globulins in the protein complex of grain.

Study results showed that proteins of sorghum variety Camelik were rich in glutelins (4.64). $64 \%$ less alkali-soluble fraction was noted in the protein of the Oniks and Kaholong varieties. They are followed by the varieties Volzhskoe 4, Topaz and Azart, which contain an average of $2.6 \%$ glutelins. The lowest value of this fraction in the protein complex of grain was present in the Koral and BaKalavr varieties.

As for the prolamine fraction, its quantitative content in sorghum proteins was generally low. The Oniks variety was distinguished by the highest amount of prolamins, while the Zhemchug, Granat, Kamelik, Avans, Bacalavr varieties had the lowest values, which did not differ statistically from each other and averaged $1.22 \%$.

In addition to the four soluble protein fractions, the sorghum grain contained an insoluble fraction, the largest amount of which was noted in the protein complex of the Azart variety. The lowest content of insoluble proteins was in the varieties Kakholong, Volzhskoe 4, Kamelik.

\section{Discussion}

Protein fractions are divided in accordance with the classification of T.B. Osborne according to the principle of solubility into groups: water-soluble - albumin; in 5-10\% sodium chloride solution - globulins; 0.1-0.2 \% sodium hydroxide solution - glutelins; 60$80 \%$ aqueous solution of alcohol - prolamins.

Each protein fraction has its own biological characteristics, including differences in amino acid composition. It is they which determine the nutritional and market value of agricultural crops. The albumin fraction has the highest biological value. In the composition of albumins, all essential acids are contained in almost optimal proportions. The globulin fraction is also characterized by a fairly balanced amino acid composition, while the amount of some essential amino acids is lower than that of albumin. Albumin and globulins have enzymatic activity. Glutelins and prolamins mainly play a spare function $[17,18]$. The glutelin fraction, including sorghum crops, is close to globulins in terms of the content of essential amino acids. It has been little studied at present, since these proteins are difficult to isolate in their pure form. The lowest biological value has the prolamine fraction - 
alcohol-soluble proteins, which are characterized by a very low content of a number of essential amino acids. In sorghum, prolamins are proteins called kafirins. It shall be noted that glutelins and prolamins in other cereals are gluten proteins, which causes a negative reaction in a large group of the population suffering from celiac disease [19].

Considering the results from the point of view of the ratio of protein fractions in sorghum grain, it can be noted that the most advantageous combination was in Zhemchug variety, where the highest value of the most valuable albumin and globulin fractions was recorded and the lowest - alcohol-soluble proteins, which are characterized by an inadequate amino acid composition. The sorghum Granat variety had almost the same indicators. Along with one of the highest indicators for albumin and globulin protein fractions, it contained few glutelins and prolamins, which are considered not the best in terms of biological value. In addition, these two varieties are included in the group of sorghum, containing the highest amount of protein in the grain. Infinity sorghum has the lowest protein content in grains in studies. However, it contains a large amount of watersoluble and salt-soluble fractions with high nutritional value. In the rest of the studied varieties, the results of the ratios of fractions were ambiguous, which indicates an uneven distribution of protein components and cannot characterize proteins in terms of biological value.

In the results obtained, it was noted that according to the percentage of each of the fractions of the protein component of sorghum, the highest amount was noted for albumin and glutelins. The same results were reflected by scientists during the study of protein fractions in flax seeds: $62.29 \%$ of albumin and $25.16 \%$ of glutelins [20]. In the study of protein fractions of lupine, on the contrary, it was proved that the predominant fraction was globulin, and then albumin, glutelins and prolamins were located in descending order [21]. These results indicate that the fractional composition of the protein component in plant seeds depends on the genetic origin of the culture.

If we analyze the quantitative content of protein fractions in sorghum grain depending on the total protein content, then we can conclude that there is no clear relationship. Earlier in the paper of Suslova T.A. it was noted that high-protein sorghum varieties differed from low-protein varieties by an increased content of the alcohol-soluble protein fraction [22]. In the present studies, this trend was not confirmed; on the contrary, grain sorghum varieties with the highest amount of protein were noted by a low level of prolamins. Wherein, it can be argued that there is a correlation between the protein content in sorghum grain and a genetic trait. Similar results can be seen in the studies of Egorova G.P. et al., where there was a positive correlation between protein content and bean genotype. Therefore, the amount of protein in bean seeds, according to the results of univariate analysis of variance, by $70.1 \%$ depends on the genetic properties of plants [23].

\section{Conclusion}

Proteins are the most expensive and scarce component of food and feed diets. Wherein, plant raw materials are the richest source of protein, the qualitative composition of which depends not only on the type of plant, but also on varietal diversity, climatic factor, ripening phase, and etc.

As a result of the analysis of the data obtained, a conclusion was made about the high potential of grain sorghum in terms of the protein component in the context of the studied varieties. Comparative evaluation showed that the quantitative ratio of protein fractions depends on the varietal origin. Considering the ratio of all types of protein fractions and all studied varieties, the highest biological value was observed in the variety Zhemchug sorghum. It had the highest amount of albumin, which is characterized by a complete amino acid composition and the lowest content of the least valuable prolamins. On the contrary, 
Kamelik and Lokus varieties were distinguished by the smallest amount of valuable watersoluble and salt-soluble protein fractions in the grain, which allows us to conclude that the content of complete proteins in these plants is insufficient.

Such studies on sorghum crops are not enough, especially on varieties of Russian selection, adapted to external conditions. In this regard, the totality of the study results obtained shows the feasibility of their application for further selection of grain sorghum for purpose of using it in the food sector.

\section{References}

1. V.S. Agibalova, T.N. Tertychnaya, E.E. Kurchaeva, I.V. Mazhulina, E.A. Andrianov, Bulletin of the Voronezh State Agrarian University, 6 (2015)

2. L.D. Erashova, G.N. Pavlova, R.S. Ermolenko, L.V. Artyukh, L.L., Food Industry, 10 (2009)

3. N.A. Petrova, O.B. Ivanchenko, Beer and drinks, 6 (2008)

4. S.A. Urubkov, S.S. Khovanskaya, S.O. Smirnov, 50, 2 (2020)

5. Book of abstracts the Second International Simposium on gluten-free cereal products and beverages, Tampere, 204 (2010)

6. I. Beitane, F. George, Nova Science Publishers (2018)

7. M. Wronkowska, M. Haros, M. Soral-Śmietana, Food and Bioprocess Technology, 6, 7 (2013)

8. N.V. Anikeeva, Bulletin of Altai State Agrarian University, 66, 4 (2010)

9. Yu.A. Matveeva, E.V. Chernova, I.A. Bazhenova, M.L. Domoroshchenkova, T.F. Demyanenko, XXI century: results of the past and problems of the present plus, 8, 2 (2019)

10. T.I. Tupolskikh, T.A. Viflyantseva, Young Researcher Dona, 11, 2 (2018)

11. S. Mallick, K. Azaz, M. Gupta, Ind. J. Plant Physiol., 18 (2013)

12. N.V. Korableva, T. D. Kasymova, Applied Biochemistry and Microbiology, 1 (2011)

13. L.M. Bokova, Z. Kh. Sultygova, M.M. Bokova, F.A. Balaeva, Z. I. Inarkieva, Rational nutrition, food additives and biostimulants, 15, 4 (2014)

14. N.V. Zaslavskaya (thesis. dis. ... cand. biol. nauk, Moscow, 1985)

15. T.B. Osborne, Vegetable Proteins, 220 (1935)

16. S.P. Martynov, AGROS 2.09 (1999)

17. A.W. Grootboom, N.L. Mkhonza, Z.O. Mbambo, M.M. Kennedy, L.S. da Silva, J. Ta ylor, J. R. N. Taylor, R. Chikwamba, L. Mehlo, Plant Cell Rep., 33 (2014)

18. D.R. Holding, Plant Science, 5 (2014)

19. D. Rajnincová, A. Špaleková, Z. Gálová, K. Romanová, J. of Food Science and Technology, 7, 1 (2019)

20. J. Chen, T. Mu, M. Zhang, D. Goffin, H. Sun, M. Ma, X. Liu, D. Zhang, Int. J. of food, 21, 1 (2018)

21. P. Gulewicz, C. Martı'nez-Villaluenga, J. Frias, D. Ciesiołka, K. Gulewicz, C.'n VidalValverde, Food Chemistry, 107 (2008)

22. T.A. Suslova (dis. ...cand. biol. nauk, L., 1984)

23. G.P. Egorova, I.N. Perchuk, A.E. Solovieva, T.V. Buravtseva, Proceedings on applied botany, genetics and breeding, 180, 2 (2019) 